\title{
Virtual Screening the Interaction of Various Compound from Indonesian Plants with the HGXPRT Enzyme to Find a Novel Antimalarial Drug
}

Wilda Nur Rohmatillah, Naura Bathari Winarto, Arthur Hariyanto Prakoso, Bawon Triatmoko, Ari Satia Nugraha*

Drug Utilitation and Discovery Research Group, Faculty of Pharmacy, University of Jember, Jember, Indonesia 68121

${ }^{*}$ Corresponding author:

E-mail: arisa-

tia@unej.ac.id

\begin{abstract}
Medicinal plants have been a notable source for antimalarial agents. This study was aimed to investigate the antimalarial potency of Indonesian medicinal plants used traditionally in malarial fever therapy. A total of 238 compounds derived from 43 plants traditionally used to alleviate malarial fever were collected and loaded into molecular docking protocol. The compounds were screened against Hypoxanthine-Guanine-XanthinePhosphoribosyltransferase (HGXPRT, 30ZF) using the AutoDock Vina software 1.1.2. The compound is important for the purine synthesis of the parasite. The experiment resulted in AM125 (20isoveratramine) from Cyanthillium patulum to possess the highest affinity with free energy $(\Delta \mathrm{G})-11 \mathrm{kcal} / \mathrm{mol}$, which is better than HGXPRT native ligands $(-6.4 \mathrm{kcal} / \mathrm{mol})$. This suggested Cyanthillium patulum was a potential source for antimalarial agents in which its constituents, 20-isoveratramine might responsible for the claims.
\end{abstract}

Keywords: HGXPRT inhibitor, molecular docking, antimalarial, Cyanthillium patulum

\section{Introduction}

One of the serious global health is Malaria. Malaria is an infectious disease caused by singlecell parasites, namely Plasmodium falciparum, Plasmodium vivax, Plasmodium malariae, Plasmodium ovale which is transmitted through the bite of Anopheles mosquitoes (Gardiner et al., 2009). Until now there are around 102 malaria-endemic countries and there are 300-500 new cases of malaria in the world. The WHO recorded there were 219 million cases of malaria in 2018 (World Health Organization, 2018). In Indonesia there were 180.205 malaria cases, the number decreased from 2017 which was 261,761 malaria cases (Kemenkes, 2019). Besides, in the same year, 2017 there were 10.7 million people who were still living in malaria-endemic areas, namely Papua, West Papua, and NTT as shown in Figure 1. Most malaria infections in eastern Indonesia were dominated by P.falciparum and P. vivax (Indonesia PK, 2018).

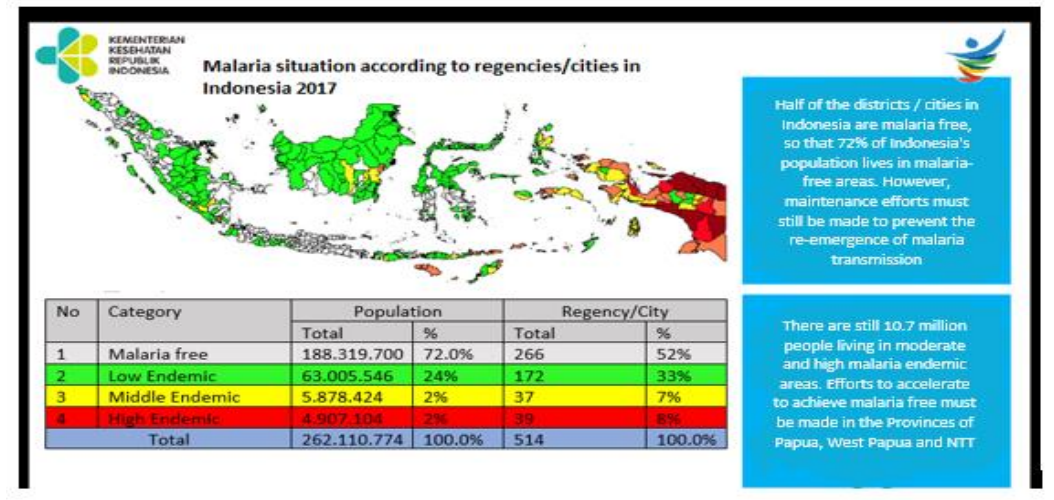

Figure 1. Cases of malaria in district / city in Indonesia (Indonesia PK, 2018)

\section{How to cite:}

Rohmatillah, W. N., Winarto, N. B., Prakoso, A. H., Triatmoko, B., \& Nugraha, A S. (2021). Virtual Screening the Interaction of Various Compound from Indonesian Plants with the HGXPRT Enzyme to Find a Novel Antimalarial Drug. The 3rd International Conference on Life Sciences and Biotechnology. NST Proceedings. pages 31-38. doi: 10.11594/ nstp.2021.0805 
To reach 2030 targeted Indonesia is free from malaria, the government is trying to eliminate malaria cases every year. However, there are challenges in carrying out these efforts, namely resistance to several anti-malarial drugs (Ditjen Pencegahan dan Pengendalian Penyakit, 2017). The cause of resistance is due to the mutation of genes from the Plasmodium parasite. The drugs used to treat malaria cases are a combination of artemisinin-based (ACT) and treatment with this drug is quite effective (Elyazar et al., 2011). However, the spread of drug administration is still uneven, so the need for the discovery of anti-malarial drugs that can be used as an alternative in the treatment of malaria.

Indonesia is a country with very biodiversity, has many herbal plants. It was recorded that more than 7,000 medical plants have been used for generation treatments including anti-malaria plants (Nugraha \& Keller, 2011). Docking can be used to try to predict the bound conformation of know binders to obtain leads for further drug development (Fias et al., 2008). This study was aimed to investigate the antimalarial potency of Indonesian medicinal plants used traditionally in malarial fever therapy. This study focused on the bioprospecting of 238 compounds from Indonesian medicinal plants commonly used as a reduction in malaria fever by the community with the enzyme Hypoxanthine-Guanine-Xanthine Phosphoribosyltransferase (HGXPRT, 30ZF). The enzymes that play a role in purine synthesis converts Hypoxanthine that is carried into the cytoplasm from plasma into inosinemonophosphate (IMP). Where IMP is then used for the next stages of nucleic acid synthesis (Downie et al., 2008).

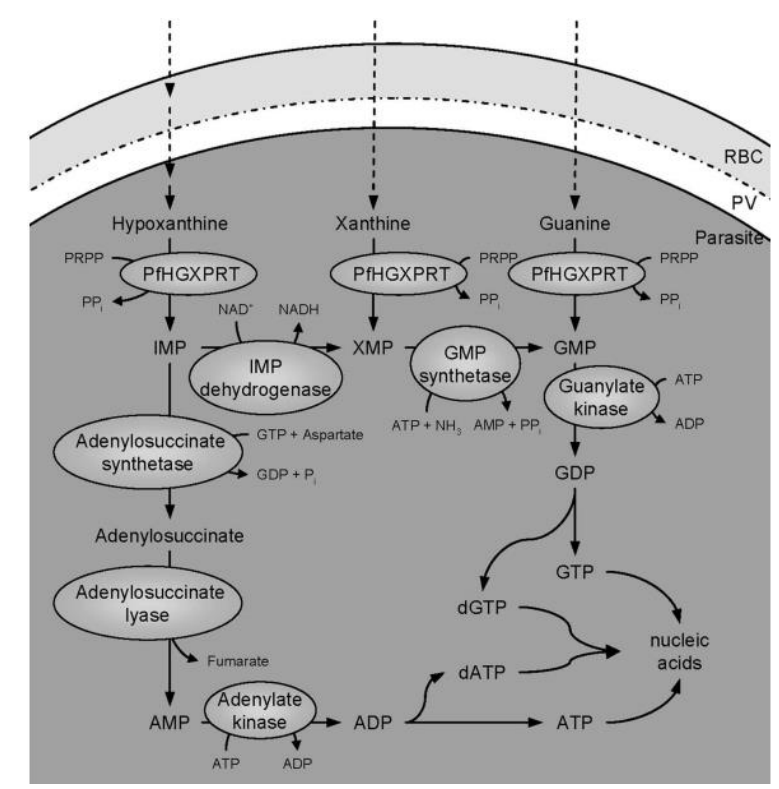

Figure 2. 3D Syntesis Nucleic acid fromP. Falciparum (Downie et al., 2008)

Purines are very important in the survival of an organism including the Plasmodium parasite. If the HGXPRT enzyme is inhibited, the IMP will not be formed and the process of nucleic acid synthesis in the parasite will fail and the parasite will die (Mbewe et al., 2007).

\section{Material and Methods}

\section{Preparation of Indonesian antimalarial plants}

Information on antimalarial plants was obtained from several related journals, the Indonesian Medicinal Plants Book, and Herb Index. A total of 238 compounds from 43 plants commonly used as fever-reducing fever in malaria cases were obtained for further analysis. 


\section{Enzyme preparation}

Enzyme preparation was started by downloading the target protein file at www.rscb.org with the ".pdb" format. The protein used is Hypoxanthine-Guanine-Xanthine Phosphoribosyltransferase (HGXPRT, 30ZF). Moreover, ligand removal was performed using Pymol software. Autodock tools were used later to prepare enzymes by adding polar hydrogen.

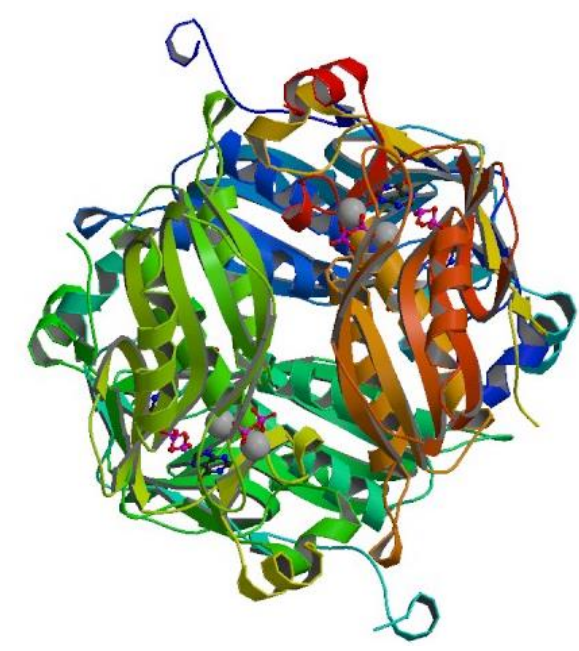

Figure 3. 3D Structure of Hypoxanthine-Guanine-Xanthine-Phosphoribosyltransferase (RSCB, 2019).

\section{Ligand preparation}

Ligand preparation begins by drawing a structure in ChemDraw or you can download it in Pubchem with the ".pdb" format. Furthermore, it is converted into 3D and optimized by minimizing energy than stored with the format ".pdbqt". The next stage was to prepare the ligands using Autodock tools and save them in the ".pdbqt" format.

\section{Griding}

Ligand preparation begins by drawing a structure in ChemDraw or you can download it in Pubchem with the ".pdb" format.

\section{Docking molecular}

This process was carried out using AutoDock Vina software 1.1.2. Enzyme and ligand files with the extension ".pdbqt" were saved in one folder as many as 238 folders according to the number of compounds. Then added conf.txt, a text with the extension ".txt" containing the file name, and the griding region of the position attached to the ligand.

\section{Visualization}

After the docking process, the results were obtained and for visualization using Pymol then the interactions are seen and the information needed is needed for further analysis.

\section{Results and Discussion}

Molecular docking can be one of the stages in a study that can provide an overview of the bonding and conformation ligand-enzymes (Pudjiastuti et al., 2014). The results of redocking the native ligand with the same binding site showed an RMSD value of 0.933Å.RMSD (Root Mean Square Deviation)is a parameter used to determine the similarity of the two structures. A good RMSD value is $<2 \AA$ (Sargsyan et al., 2017). Besides RMSD, free energy $(\Delta G)$ is also a parameter used in this study. Free energy is used as a sign of affinity, which is more negative, indicating a 
higher affinity. Affinity shows the strength of ligand binds with the receptor. The higher affinity indicates ligand binding with the stronger receptor (Pratama \& Aziz, 2019). Because all free energy values are negative, it shows that interactions between all test ligands and receptors on enzymes occur spontaneously (Vikram Sin \& Mishra, 2019).

Of the 238 compounds, there are 5 compounds with the best interaction with the HGXPRT enzyme shown in Table 1 namely AM39, AM59, AM65, AM125, AM200. Each compound was isolated from Indonesian medicinal plants respectively Blumea balsamifera, Bursera simatuba, Caesalpinia crista, Cyanthillium patulum, and Senna siamea (Saewan et al., 2011; Peraza-Sanchez \& Pena-Rodriguez, 1992; Kumar et al., 2014; Tezuka et al., 1998; Kumar et al., 2013). That plant is used to treat malaria by people in various regions (Septiana et al., 2017; Badan Penelitian dan Pengembangan Kesehatan, 2006). Previous research related to the treatment of malaria with plant extracts has been done, but the mechanism does not exist. This interaction occurs because the residual amino acid bond with the hydrogen bond is shown in Figures $4-9$. The native ligand can bind to $-6.4 \mathrm{kcal} / \mathrm{mol}$ of energy needed and the five compounds of the bind requires less energy than the native ligand. There are $-10.5,-10.9,-10.4,-11.0$, and $-10.6 \mathrm{kcal} / \mathrm{mol}$ and the compound which has the highest potential is AM125, which is a 20-isoveratramine compound from the Cyanthillium patulum plant with free energy $-11.0 \mathrm{kcal} / \mathrm{mol}$. Each of the five compounds interacted with different amino acids of HGXPRT enzyme (Table 2). AM39 is hydrogen-bonded with two amino acids, SER91 and ASN47. AM59 binds only to amino acids, namely ARG80 whereas AM65 has a bond with amino acids reside, LYS51, LYS88, THR84, and ARG210. AM200 compounds interacted with only one amino acid, TYR201. Four amino acids of the HGXPRT enzyme produced intermolecular bonding with AM65. Although AM65 interacted with 4 amino acids than AM125 (3 amnio acid interaction), aliphatic residue on AM65 prevents the molecules to use less energy during the interaction. The high value of affinity not only dependent on the number of amino acids which interact with the compounds, but also on the molecular properties of the ligand. These properties included also molecular weight and polarity. With these results, AM125 compound (20isoveratramine) can be used as an IMP formation inhibitor which deters Plasmodium life cycle through nucleic acids synthesis inhibition. AM125 compound (20-isoveratramine) is one of Cyanthillium patulum constituents in which the medicinal plant has been used by Indigenous people of Indonesia to treat malarial fever. This investigation supports Cyanthillium patulum as the source anti-malarial agen

Tabel 1. Results of the 5 best docking compounds

$\begin{array}{llll}\text { Code Name Plant Source } & \text { Structure and Compound }\end{array}$

Blumea
balsamifera
tinued

(Luteolin-7-methyl-ether) 


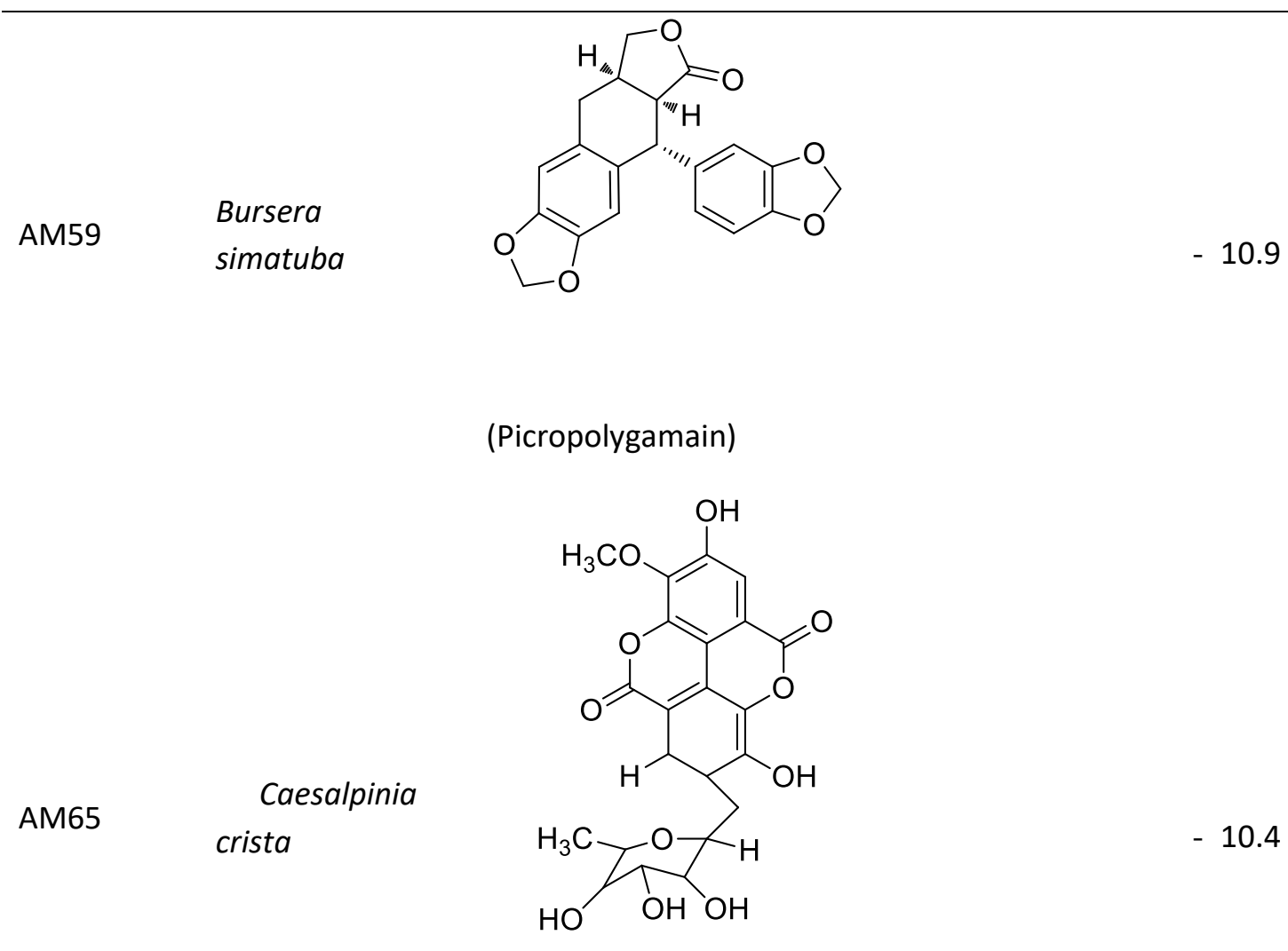

(3-O-Methylellagic acid-3'O- $\alpha$ -

rhamnopyranoside)

Cyanthillium
patulum

(20-isoveratramine)

AM200 Senna siamea<smiles>Cc1cc2c(c(O)c1-c1c(C)cc3c(c1O)C(=O)c1c(O)cccc1C3=O)C(=O)c1cc(O)cc(O)c1C2=O</smiles>

(Cassiamin A) 
Tabel 1. Amino acid residues

\begin{tabular}{lllllll}
\hline Ligand & $\begin{array}{l}\text { HGXPRT } \\
\text { Ligand }\end{array}$ & AM39 & AM59 & AM65 & AM125 & \multirow{2}{*}{ AM200 } \\
\hline Amino acid & ASP204 & SER91 & \multirow{2}{*}{ ARG80 } & LYS88 & GLY81 & \\
residues & VAL198 & ASN47 & & THR84 & THR84 & TYR201 \\
& & & & ALA85 & \\
\hline
\end{tabular}

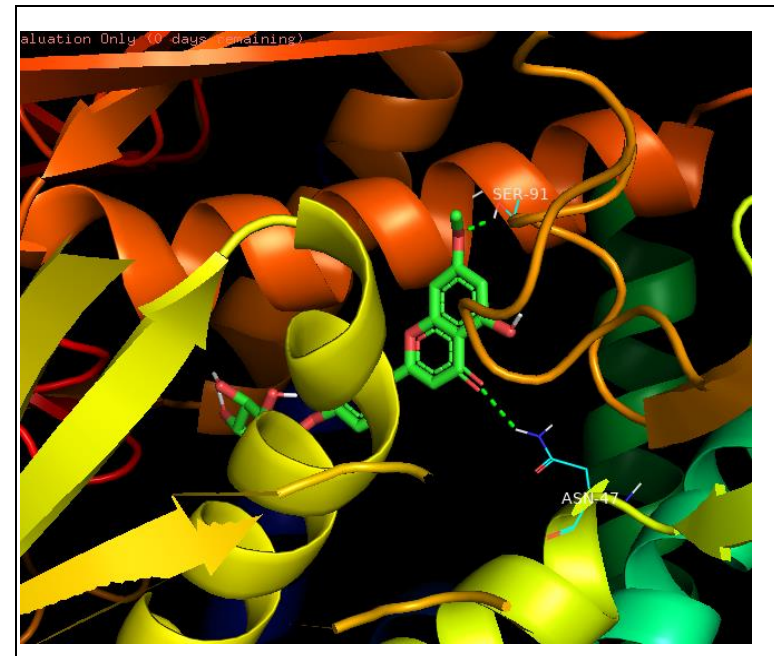

Figure 4. Interaction visualization AM39 against HGXPRT showing hydrogen bonding with SER91 and ASN47

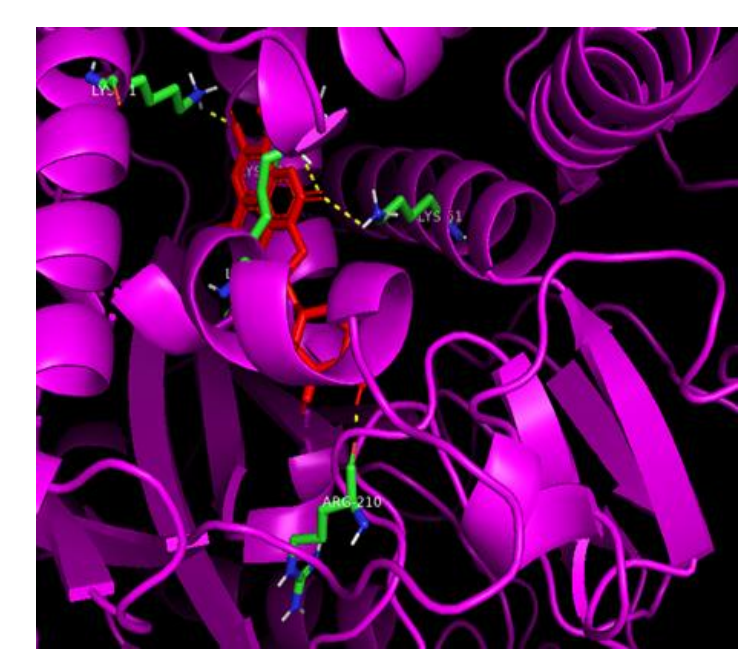

Figure 6. Interaction visualization AM65 against HGXPRT showing hydrogen bonding with LYS51, LYS88, THR84 and ARG210

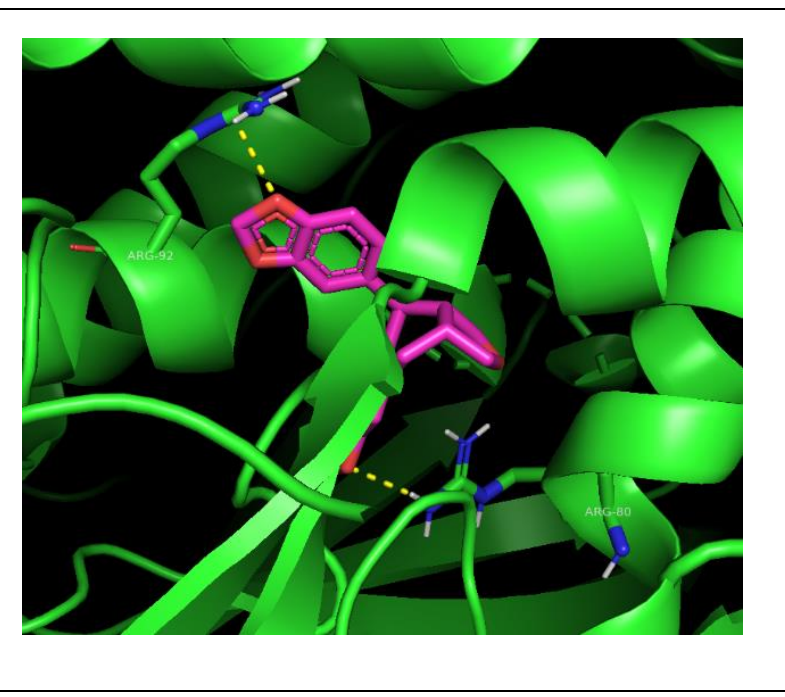

Figure 5. Interaction visualization AM59 against HGXPRT showing hydrogen bonding with ARG92 andARG80

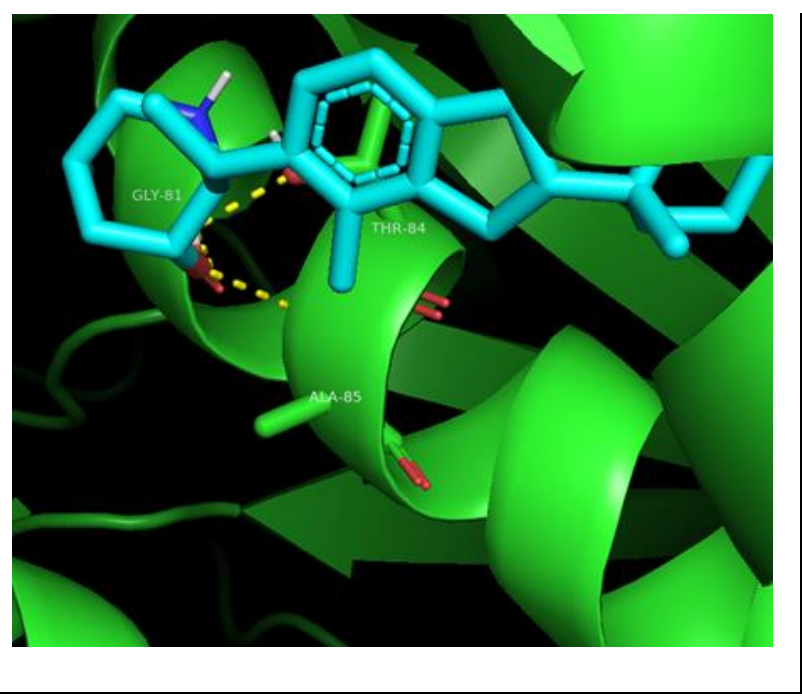

Figure 7. Interaction visualization AM125 against HGXPRT showing hydrogen bonding with GLY81, THR84, and ALA85 


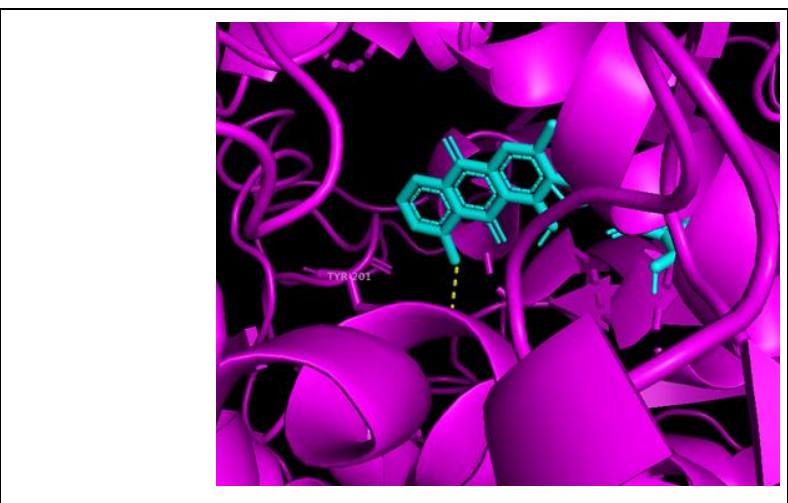

Figure 8. Interaction visualization AM200 against HGXPRT showing hydrogen bonding with TYR201

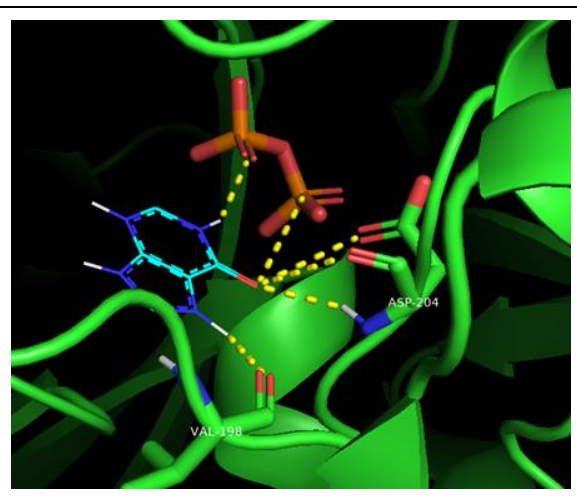

Figure 9. Interaction visualization Native Ligand hydrogen bonding with ASP204 and VAL198

\section{Conclusion}

In conclusion, a computational-based experiment successfully discovers 20 -isoveratramine to have the best fit as an antimalarial candidate. The study revealed the potency of the Indonesian medicinal plant, Cyanthillium patulum, as a source for anti-malarial agents

\section{Acknowledgment}

Authors thanks to University of Jember for research support.

\section{References}

Badan Penelitian dan Pengembangan Kesehatan. (2006). .Inventaris tanaman obat Indonesia Vi. Dalam Tanaman Obat Indonesia. Jakarta:Departemen Kesehatan RI

Ditjen Pencegahan dan Pengendalian Penyakit. (2017). Buku saku penatalaksanaan kasus malaria. Jakarta: Kementrian Kesehatan RI Downie, M. J., Kirk, K., \& Mamoun, C. B. (2008). purine salvage pathways in the intraerythrocytic malaria parasite Plasmodium falciparum. Eukaryotic Cell, 7(8), 1231-7. doi: 10.1128/EC.00159-08

Elyazar, I. R. F., Hay, S. I., \& Baird, J. K. (2011). Malaria distribution, prevalence, drug resistance and control in Indonesia. Advances in Parasitology, 74, 41-175. doi: 10.1016/B978-0-12-385897-9.00002-1.

Fias, S., Damme, S. V., \& Bultinck, P. (2008). Multidimensionality of Delocalization Indices and Nucleus Independent Chemical Shifts in Polycyclic Aromatic Hydrocarbons. Computers \& Chemistry, 29(3), 358-66.

Gardiner, D. L., Skinner-Adams, T. S., Brown, C. L., Andrews, K. T., Stack, C. M., McCarthy, J. S., Dalton, J., \& Trenholme, K. (2009). Plasmodium falciparum: New Molecular Targets with Potential for Antimalaria Drug Development. Expert Review of Anti-Infective Therapy1087-98

Indonesia PK. (2018). Profil Kesehatan Indonesia.

Kasahara, S., \& Hemmi, S. (1995). Medical herb index in Indonesia. Jakarta:P.T.Eisai Indonesia

Kemenkes. (2019). Pusat data dan informasi profil kesehatan Indonesia 2018

Kumar, A., Garg, V., Chaudhary, A., Jain, P. K., \& Tomar, P. K. (2014). Isolation, characterisation and antibacterial activity of new compounds from methanolic extract of seeds of Caesalpinia crista L. (Caesalpinaceae). Natural Product Research, 28(4), 230-8. https://doi.org/10.1080/14786419.2013.814054

Kumar, D., Karmase, A., Jagtap, S., Shekhar, R., \& Bhutani, K. K. (2013). Pancreatic lipase inhibitory activity of cassiamin A, a bianthraquinone from Cassia siamea P. Natural Production Communications, 8(2), 195-8

Mbewe, B., Chibale, K., \& McIntosh, D. B. (2007). Purification of Human Malaria Parasite Hypocanthine Guanine Xanthine Phosphoribosyltransferase (HGXPRT) using immobilized reactive red 120. Protein Expression and Purification, 52(1), $153-8$.

Nugraha, A. S., \& Keller, P. A. (2011). Revealing indigenous Indonesian traditional medicine: Anti-infective agents. Natural Product Communications, 6(12), 1953-66

Peraza-Sánchez, S. R., Peña-Rodríguez, L. M. (1992). Isolation of picropolygamain from the resin of bursera simaruba. Journal of Natural Products, 55(12), 1768-71. doi: 10.1021/np50090a009. 
Pratama, M., \& Aziz, I. (2019). Molecular docking of bawang dayak (Eleutherine bulbosa) secondary metabolites as bacterial cell wall synthesis inhibitor. Conference: 1st International Conference on Science and Technology, ICOST 2019, 2-3 May, Makassar, IndonesiaAt: Makassar, Indonesia. doi: 10.4108/eai.2-5-2019.2284686

Pudjiastuti, P., Sumarsih, S., Arwati, H., Amalina, I., Fanani, M. Z., Utomo, E. P., Fitri, L. E., Nugraha, A. S., Lie, W., Pyne, S. G. (2014). Epicroomine and croomine from Stemona tuberosa antimalarial drug for inhibiting dihydrofolate reductase (DHFR) activity and their molecular modeling. Journal of Chemical and Pharmaceutical Research, 6(6), 544-8.

RSCB. (2019). PDB - 3 OZF: Crystal Structur of Plasmodium falciparum Hypoxanthine-Guanine-Xanthine Phosphoribosyltransferase in Complex with Hypoxanthine [cited 2019 Nov 8] Available from: http://www.rscb.org/structure/3ozf

Saewan, N., Koysomboon, S., \& Chantrapromma, K. (2011). Anti-tyrosinase and anti-cancer activities of flavonoids from Blumea balsamifera DC. Journal of Medicinal Plants Research, 5(6), 1018-25

Sargsyan, K., Grauffel, C., \& Lim, C. (2017). How molecular size impacts RMSD applications in molecular dynamics simulations. Journal of Chemical Theory and Computation, 13(4), 1518-24

Septiana, E., Umaroh, A., Gangga, E., \& Simanjuntak, P. (2017). Aktivitas penghambatan polimerisasi heme ekstrak daun sembung ( Blumea balsamifera ) sebagai antimalaria. Buletion Littro, 28(1) 29-36.

Tezuka, Y., Kikuchi, T., Zhao, W., Chen, J., \& Guo, Y. (1998). Two new steroidal alkaloids, 20-isoveratramine and verapatuline, from the roots and rhizomes of Veratrum patulum. Journal of Natural of Production, 61(9), 1078-81

Vikram Sin, I., \& Mishra, S. (2019). Molecular docking studies of benzamide derivatives for PfDHODH inhibitor as potent antimalarial agent. American Journal of Biochemistry and Molecular Biology, 9(1), 1 - 6

World Health Organization. (2018). World Malaria Report, 7(9), https://www.who.int/malaria/publications/world-malaria-report2018/en/ 